\author{
Julian Jezioro \\ Uniwersytet Wrocławski \\ e-mail: julian.jezioro@uwr.edu.pl \\ ORCID: 0000-0001-7378-000X
}

\title{
PRZEJŚCIE I KORZYSTANIE \\ Z AUTORSKICH PRAW MAJĄTKOWYCH \\ W RAMACH ZAMÓWIEŃ PUBLICZNYCH - \\ ZASADY OGÓLNE ORAZ WYBRANE \\ ZAGADNIENIA PRAKTYCZNE
}

\section{TRANSFER AND USE OF COPYRIGHTS \\ IN PERFORMANCE OF PUBLIC CONTRACTS - \\ GENERAL RULES AND SELECTED \\ PRACTICAL ASPECTS}

DOI: $10.15611 /$ pn.2018.540.15

JEL Classification: K23

Streszczenie: Przedmiotem zamówień publicznych mogą być przedmioty praw wyłącznych, o których mowa w art. 67 ust. 1 pkt b Ustawy z dnia 29 stycznia 2004 r. Prawo zamówień publicznych (PZP) - w tym utwory objęte uregulowaniem Ustawy z dnia 4 lutego $1994 \mathrm{r}$. o prawie autorskim i prawach pokrewnych. Zwykle są one przedmiotem dostawy lub usługi. Przepisy ustawy o prawie autorskim dotyczące stosunków umownych w dość szerokim zakresie modyfikują i uzupełniają zasady zawierania tych umów, wynikających z Kodeksu cywilnego. W opracowaniu wskazano wybrane problemy praktyczne, jakie mogą się pojawić przy konstruowaniu podstaw prawnych konkretnych stosunków, w tym najważniejsze odmienności uregulowania szczególnego prawa autorskiego. Ilustracją prowadzonych rozważań są przykłady umów zawieranych w ramach uregulowania dotyczącego partnerstwa innowacyjnego (art. 73h Prawa zamówień publicznych) oraz w ramach konkursów.

Słowa kluczowe: utwory, artystyczne wykonania, bazy danych, umowy dotyczące zamówień publicznych, przeniesienie praw autorskich, licencja, partnerstwo inwestycyjne.

Summary: An object of a contract awarded under public procurement procedure may be an object of exclusive rights, referred to in art. $67 \mathrm{sec} .1$ item $\mathrm{b}$ of the public procurement law (PPL) including works to which copyrights and related rights act apply. Usually, they are the objects of delivery or service provision. Copyrights law regulations concerning contractual relationships quite broadly modify and supplement the rules on executing such contracts provided for in the civil code. The publication presents regulations of the copyrights act concerning execution of public contracts, featuring selected practical problems that may 
arise when establishing legal framework for specific legal relationships. Highlighted in the paper are major differences between specific regulations on execution of contracts that are found in copyrights law and general principles laid down in the civil code. The discussion is illustrated with examples of contracts executed under provisions on innovation partnerships (art. 73h PPL) and contract awarding competitions.

Keywords: works, artistic performance, data base, public contract, transfer of copyrights, license, investment partnership.

\section{Wstęp}

Przedmiotem zamówień publicznych mogą być przedmioty praw wyłącznych, o których mowa w art. 67 ust. 1 pkt b Ustawy z dnia 29 stycznia 2004 r. Prawo zamówień publicznych ${ }^{1}-$ w tym utwory objęte uregulowaniem Ustawy z dnia 4 lutego $1994 \mathrm{r}$. o prawie autorskim i prawach pokrewnych ${ }^{2}$. Zwykle będą one przedmiotem dostawy (2 pkt. 2/PZP) lub usługi (2 pkt. 10/ PZP), a więc umów, których celem jest albo nabycie już istniejących dóbr lub upoważnienia do korzystania z nich (przykładowo uzyskanie licencji na korzystanie z oprogramowania komputerowego), albo ich stworzenie - w ramach umowy o dzieło lub umów, do których stosuje sie przepisy o zlecenia na podstawie art. $750 \mathrm{KC}$. W praktyce oznacza to, że mogą to być bardzo różne stosunki prawne.

Punktem wyjścia dla prowadzonych tu rozważań jest stwierdzenie, że przepisy PrAut dotyczące stosunków umownych w dość szerokim zakresie modyfikują i uzupełniają zasady wynikające z Kodeksu cywilnego, do których odsyła przepis art. 139 PZP. Cechą charakterystyczną tego uregulowania jest wprowadzenie wspólnej, ogólnej regulacji w odniesieniu zarówno do rozporządzania prawami autorskimi, jak i korzystania z nich. Zasady te, pomieszczone głównie w art. 41-68 PrAut, znajdą zastosowanie do nieomal każdej umowy zawieranej w celu udzielenia zamówienia publicznego. Przy czym przepisy art. 66-68 PrAut dotyczą wyłącznie umów licencyjnych, czy też ściślej - umów zawierających upoważnienie do korzystania z utworów. Opracowanie to ma na celu ogólną prezentację tego uregulowania PrAut oraz odniesienie go do zasad dotyczących umów zawieranych w sprawie zamówień publicznych ze wskazaniem wybranych problemów praktycznych, jakie mogą się pojawić przy konstruowaniu podstawy konkretnych stosunków, jaką jest umowa.

W praktyce w świetle postanowień przepisów PrAut możliwe jest ukształtowanie skonkretyzowanego stosunku według trzech podstawowych modeli różniących się zakresem i charakterem nabywanych uprawnień, co każdorazowo wymaga odniesienia do konkretnego celu zamówienia publicznego i wstępnego dokonania właściwego wyboru jednego z tych „modeli”. Stąd też wstępnym ustaleniem dotyczącym

\footnotetext{
${ }^{1}$ Tekst jedn.: Dz.U. z 2018 r., poz. 1986 ze zm.; dalej zamiennie: PZP.

${ }^{2}$ Tekst jedn.: Dz.U. z 2018 r., poz. 1191 ze zm.; dalej zamiennie: PrAut.
} 
konkretnego zamówienia publicznego powinna być ocena zmierzająca do dostosowania jego celu do jednej z tych możliwości. Ma to istotne znaczenie ze względów ekonomicznych, każdy bowiem z tych „modeli” powoduje odmienny skutek w tym zakresie, co w praktyce obrotu powinno także wpływać na wielkość ekwiwalentu za jego osiągnięcie, a tym samym koszty (zasadniczo cenę w rozumieniu art. 2 pkt 1/PZP), jakie należy ponieść w celu realizacji konkretnego zamówienia publicznego.

W aktualnym stanie prawnym w odniesieniu do praw autorskich (także w pewnym zakresie do przedmiotów praw pokrewnych i praw do baz danych w rozumieniu art. 2 ust. 1 pkt 1 ustawy z dnia 27 lipca 2001 r.) możliwe jest zawarcie umowy, która będzie podstawą albo nabycia ogółu praw autorskich majątkowych, albo nabycia jedynie części uprawnień tworzących prawo autorskie do skonkretyzowanego utworu obejmujących określone pola eksploatacji, lub uzyskanie jedynie uprawnień do korzystania w pełnym lub ograniczonym zakresie - na zasadzie wyłączności lub w ramach licencji niewyłącznej. Są to podstawowe czynności prawne występujące w obrocie prawami do utworów (także odpowiednio przedmiotów praw pokrewnych i baz danych sui generis), które mogą dotyczyć także zamówień publicznych.

Dla pełności obrazu dodajmy, że w praktyce obrotu możliwe jest ponadto oddanie praw autorskich w dzierżawę (zob. art. $709 \mathrm{KC}$ ), obciążenie autorskich praw majątkowych niektórymi ograniczonymi prawami rzeczowymi - użytkowaniem (zob. art. $265 \mathrm{KC}$ ), a także zastawem (zob. art. $327 \mathrm{KC}$ ). A ze względu na treść art. 33 pkt 9 KRO możliwe jest umowne rozszerzenie małżeńskiej wspólności ustawowej o prawa autorskie stanowiące element majątku osobistego jednego z małżonków. Prawa autorskie majątkowe (także upoważnienie do korzystania z utworu) może być przedmiotem wkładu (aportu) do spółki cywilnej (zob. art. $861 \mathrm{KC}$ ) lub handlowej, a także stanowić przedmiot przyrzeczenia publicznego (głównie konkursowego zob. $921 \S 3 \mathrm{KC}$ ). Sytuacje te dla praktyki zamówień publicznych nie mają większego znaczenia i nie wymagają tu omówienia.

Przeniesienie praw autorskich majątkowych, w aktualnym stanie prawnym ${ }^{3}$, następuje na podstawie umów nazwanych, uregulowanych w KC, lub nienazwanych, zawieranych w ramach swobody kształtowania treści umowy zgodnie $\mathrm{z}$ art. $353^{1} \mathrm{KC}$. W praktyce będzie to zwykle umowa sprzedaży praw autorskich, jeśli zamawiany w trybie zamówień publicznych utwór już istnieje, oraz umowa o dzieło albo umowa o świadczenie usług, do której na podstawie art. $750 \mathrm{KC}$ znajdą przepisy o zleceniu (zob. 734 i n. KC), jeśli utwór taki ma powstać w wyniku wykonania zobowiązania umownego. $\mathrm{Z}$ analogiczną sytuacją będziemy mieli do czynienia w przypadku nabywania $\mathrm{w}$ ramach zamówienia publicznego jedynie licencji (upoważnienia do korzystania z utworu), jeśli dotyczyć to będzie utworów, które mają dopiero powstać jako wynik wykonania umowy w sprawie zamówienia publicznego. Natomiast podstawą

${ }^{3}$ Do wejścia w życie PrAut - na podstawie przepisów ustawy z 10 lipca 1952 r. - ustawodawca regulował jako umowę nazwaną służącą przeniesieniu praw umowę wydawniczą; uregulowanie to nie zostało przejęte do obecnie obowiązujących przepisów. 
dla nabycia uprawnień do korzystania z utworów powinna być umowa licencyjna, do której znajdą zastosowanie, poza regulacją ogólną, przepisy art. 65-68 PrAut.

W takiej też kolejności zostanie tu omówione istotne z punktu widzenia zamówień publicznych uregulowanie PrAut dotyczące tych umów.

\section{Zasady ogólne dotyczące przeniesienia praw autorskich oraz udzielenia upoważnienia do korzystania z nich}

Zgodnie z art. 52 ust. 1 i 2 PrAut, jeżeli umowa nie stanowi inaczej, przeniesienie własności egzemplarza utworu nie powoduje przejścia autorskich praw majątkowych do utworu - odpowiednio w takiej samej sytuacji przejście autorskich praw majątkowych nie powoduje przeniesienia na nabywcę własności egzemplarza utworu. Przyjmuje się, że uregulowanie to wprowadza „regułę autonomiczności” wymienionych w nim praw i wprowadza bardzo istotne dyrektywy dla wykładni umów mających za przedmiot utwory i ich materialne nośniki ${ }^{4}$. Zawarcie umowy, na podstawie której następuje jedynie przeniesienie własności egzemplarza utworu (w tym oryginalnego), nie pociąga za sobą skutku w zakresie przejścia praw autorskich (odnieść to należy odpowiednio przynajmniej do licencji wyłącznej). Odpowiednio umowa, na podstawie której następuje przeniesienie praw autorskich, nie skutkuje przejściem prawa własności do rzeczy, w której utrwalono utwór. Odnosząc to do praktyki konstruowania umów (w tym w sprawie zamówień publicznych), należy stwierdzić, że z zasad tych wynika konieczność objęcia postanowieniami klauzul umownych zarówno skutku rzeczowego dotyczącego nośnika materialnego, stanowiącego utrwalenie utworu, jak i przeniesienia praw autorskich (upoważnienia do korzystania z nich), jeśli konkretna umowa ma oba te skutki wywołać. Poniżej omówiono głównie kwestie praktyczne związane z konstruowaniem klauzul dotyczących przeniesienia praw autorskich oraz upoważnienia do korzystania z utworu.

Na wstępie należy wskazać na istotne w stosunku do zasad kodeksowych ograniczenia swobody umów wynikające $\mathrm{z}$ uregulowania o charakterze bezwzględnie wiążącym.

W pierwszym rzędzie dotyczą one zakresu nabywanych uprawnień w ramach tzw. pól eksploatacji, czyli sposobów korzystania z utworu. Ustawodawca w art. 41 ust. 4 PrAut dopuszcza nabycie jedynie uprawnień w zakresie tych pól eksploatacji utworu, które są znane w chwili zawarcia umowy. Oznacza to, że nie można skutecznie zapewnić sobie definitywnego nabycia ,pełnego" zakresu uprawnień w stosunku do konkretnego utworu, a zasadniczo należy liczyć się z koniecznością ponownego udzielenia zamówienia publicznego, jeśli takie nowe sposoby korzystania pojawią się już po zawarciu konkretnej umowy. Można zauważyć, że właśnie takich sytuacji dotyczy uregulowanie art. 67 ust. 1 pkt 1 i 1a PZP. Rygoryzm ten ule-

${ }^{4}$ Zob. J. Barta, R. Markiewicz, [w:] Prawo autorskie i prawa pokrewne. Komentarz, Kraków 2005, s. $454-455$. 
ga złagodzeniu jedynie w przypadkach wskazanych w art. 41 ust. 5 PrAut. Zgodnie z tym przepisem: „twórca utworu wykorzystanego lub włączonego do utworu audiowizualnego oraz utworu wchodzącego w skład utworu zbiorowego, po powstaniu nowych sposobów eksploatacji utworów, nie może bez ważnego powodu odmówić udzielenia zezwolenia na korzystanie $\mathrm{z}$ tego utworu w ramach utworu audiowizualnego lub utworu zbiorowego na polach eksploatacji nieznanych w chwili zawarcia umowy". Jak się wydaje, ma to bardzo ograniczone czy wręcz znikome znaczenie dla obrotu w zakresie zamówień publicznych.

Istotniejszy problem praktyczny wiąże się jednak z zasadami wynikającymi $\mathrm{z}$ art. 41 ust. 2 PrAut. Zgodnie z tym przepisem: „Umowa o przeniesienie autorskich praw majątkowych lub umowa o korzystanie z utworu, zwana dalej «licencją», obejmuje pola eksploatacji wyraźnie w niej wymienione". Literalne brzmienie tego przepisu może być interpretowane w ten sposób, że oznacza to konieczność specyfikacyjnego określenia zakresu takich pól eksploatacji jako warunku skuteczności konkretnej umowy. W praktyce może okazać się to bardzo trudne do zrealizowania, zwłaszcza jeśli realizacja zamówienia publicznego ze względu na jego skonkretyzowany cel wymaga nabycia ogółu uprawnień - obejmujących wszystkie pola eksploatacji konkretnego utworu. Problem jest o tyle trudny do rozstrzygnięcia, że w literaturze można spotkać zarówno interpretacje postulujące bardzo restrykcyjną ${ }^{5}$ wykładnię tego uregulowania, jak i podejście bardziej „liberalne”, które podziela także autor tego opracowania.

Za trafną należy uznać ocenę, że omawiany przepis został językowo sformułowany ,zbyt rygorystycznie" w stosunku do realiów obrotu. Analiza orzecznictwa dotyczącego interpretacji art. 41 ust. 2 PrAut wskazuje, że w razie braku wymienienia pól eksploatacji w umowie sądy zapewne będą je ustalać przy zastosowaniu reguł wykładni oświadczeń woli z art. $65 \S 2 \mathrm{KC}^{7}$, a więc w tym zakresie zdaje się dominować wykładnia ,liberalna”. Nie zmienia to jednak postulatu, aby zwłaszcza w umowach dotyczących zamówień publicznych, zasady wynikające z art. 41 ust. 2 PrAut były realizowane w sposób ograniczający możliwość zakwestionowania założonych w tym trybie celów zawarcia konkretnej umowy. Stąd też poza jednoznacznym określeniem, czy umowa ma na celu nabycie autorskich praw majątkowych czy jedynie upoważnienie do korzystania z nich, istotne jest takie formułowanie konkretnych klauzul umownych, aby nie było wątpliwości, jakich pól eksploatacji i jakich utworów konkretna umowa dotyczy. Przede wszystkim ogólne określenie, z którego wynika zamiar przeniesienia „ogółu” lub „wszystkich” praw autorskich,

${ }^{5}$ Zob. T. Targosz, [w:] T. Targosz, K. Włodarska, Umowy przenoszace autorskie prawa majątkowe, Warszawa 2010, s. 26 i n.

${ }^{6}$ Zob. m.in. J. Szczotka, Naruszenie wymogu specyfikacji pól eksploatacji utworu, [w:] Współczesne problemy prawa handlowego. Księga jubileuszowa dedykowana prof. dr hab. Marii Poźniak-Niedzielskiej, red. A. Kidyba, R. Skubisz, Kraków 2007, s. 379.

${ }^{7}$ Tak J. Barta, R. Markiewicz, Prawo autorskie, Warszawa 2016, s. 339 i przywołane tam orzecznictwo. 
może okazać się niewystarczające dla osiągnięcia prawnego skutku w odniesieniu do określonego katalogu pól eksploatacji. Postulat ten wiąże się z kolejnym dyskutowanym w literaturze problemem praktycznym dotyczącym konstruowania klauzul umownych - kwestią konieczności stosowania w zawieranych w obrocie umowach nazewnictwa (terminologii) ustawowej wynikającej z przykładowego katalogu pól eksploatacji zawartego $\mathrm{w}$ art. $50 \mathrm{PrAut}^{8}$.

Należy zgodzić się z oceną, że PrAut nie wprowadza ścisłego obowiązku stosowania terminologii ustawowej, byle nie budziło to wątpliwości co do zakresu objętych umową pól eksploatacji ${ }^{9}$, a co więcej - ewentualne wątpliwości w tym zakresie mogą być wyjaśniane na drodze ogólnych zasad wykładni oświadczenia woli (zob. art. $65 \mathrm{KC})^{10}$. J. Barta i R. Markiewicz na podstawie analizy orzecznictwa sądowego oceniają, że na wypadek sporu o skuteczność umowy, w której brak jest wskazania pól eksploatacji, sąd uzna za skuteczną umowę licencji niewyłącznej, ustalając zakres uzyskanych uprawnień (pól eksploatacji) przez licencjobiorcę przy zastosowaniu reguł z art. $65 \S 2 \mathrm{KC}^{11}$. Podobna ocena dotyczy możliwości konwersji na niewyłączną umowę licencyjną - umowy zawartej z zamiarem nabycia praw autorskich lub umowy licencji wyłącznej ${ }^{12}$. Jeśli jednak odniesiemy to do umów dotyczących zamówień publicznych, to oczywiste jest, że ewentualne naruszenie omawianych tu zasad może zagrozić realizacji celu, dla którego umowa taka została zawarta, a więc postulat stosowania weryfikowalnej, bo mającej odbicie w uregulowaniu prawnym, terminologii w umowach dotyczących zamówień publicznych ma istotne znaczenie dla prawidłowości praktyki w tym zakresie.

$\mathrm{Z}$ uregulowania ustawowego wynika także, że nieważna jest umowa w części dotyczącej wszystkich utworów lub wszystkich utworów określonego rodzaju tego samego twórcy mających powstać w przyszłości (art. 41 ust. 3 PrAut) oraz zastrzeżenie formy pisemnej pod rygorem nieważności dla umów przenoszących prawa autorskie oraz umowy zawierającej udzielenie licencji wyłącznej (zob. art. 53 oraz 67 ust. 5 PrAut). Ta ostatnia zasada nie dotyczy umów zawierających upoważnienie licencyjne w zakresie licencji niewyłącznej. Można w tym miejscu wskazać, że przepisy PZP w odniesieniu do kwestii formy umowy idą dalej, skoro każda umowa w sprawach zamówień publicznych powinna być zawarta formie pisemnej pod tym rygorem, chyba że przepisy odrębne wymagają formy szczególnej (art. 139 ust. 2 PZP).

Zgodnie z kolejną zasadą PrAut, dotyczącą przeniesienia praw autorskich umowa zawierająca zobowiązanie do przeniesienia autorskich praw majątkowych przenosi je na nabywcę $\mathrm{w}$ zakresie określonych w umowie pól eksploatacji $\mathrm{w}$ chwili

${ }^{8}$ Zob. m. in.: P. Żerański, Formy umów autorskich na tle zasady specyfikacji, Glosa, 2007, nr 3, s. $68 \mathrm{in}$.

${ }^{9}$ Tak J. Barta, R. Markiewicz, wyd. cyt., s. 334 i n. z powołaniem się na orzecznictwo: m.in. na wyrok SN z 3 grudnia 2008 r., V CNP 82/08, LEX nr 484683 oraz z 14 września 2005 r., III CKN 124/05, LEX nr 164184.

${ }^{10}$ Por. SN w wyroku z 3 grudnia 2008 r., V CNP 82/08, LEX nr 484683 i z 8 października 2004 r., V CK 670/03 OSNC 2005, nr 9, poz. 162.

${ }^{11}$ J. Barta, R. Markiewicz, wyd. cyt., s. 338.

${ }^{12}$ Tamże. 
przyjęcia utworu (art. 64 PrAut) i w tym zakresie w odniesieniu do umów w sprawie zamówień publicznych zdaje się nie rodzić istotnych problemów praktycznych.

Cały szereg przepisów PrAut dotyczy wynagrodzenia należnego twórcy - przepisy te wyraźnie wzmacniają sytuację twórcy. Przepis art. 45 PrAut wprowadza obowiązek zapłaty wynagrodzenia za korzystanie z utworu na każdym odrębnym polu eksploatacji (art. 45 PrAut). Ustawa wprowadza też powiązaną z tym regułę interpretacyjną mówiącą o tym, że brak w umowie postanowienia, iż przeniesienie autorskich praw majątkowych lub udzielenie licencji nastąpiło nieodpłatnie powoduje, że twórcy przysługuje prawo do wynagrodzenia (art. 43 ust. 1 PrAut). Wynika z tego, że także w umowach w sprawie zamówień publicznych, klauzule dotyczące zakresu nabywanych uprawnień w odniesieniu do pól eksploatacji powinny być ściśle powiązane $\mathrm{z}$ określeniem wynagrodzenia - w taki sposób, aby wynikało z nich jednoznacznie, za jakie sposoby korzystania $z$ utworu wynagrodzenie to jest należne. Ewentualny spór w tym zakresie będzie rozstrzygany z uwzględnieniem zasad $\mathrm{z}$ art. 43 ust. 2 PrAut, który wskazuje jako podstawę do ustalenia wysokości wynagrodzenia zakres udzielonego prawa oraz zakres korzyści wynikających z korzystania $\mathrm{z}$ utworu (art. 43 ust. 2 PrAut).

Kolejna kwestia praktyczna, jaką należy się zająć, związana jest z uregulowaniem art. 46 PrAut. Zgodnie z tym przepisem jeżeli umowa nie stanowi inaczej, twórca zachowuje wyłączne prawo zezwalania na wykonywanie zależnego prawa autorskiego, mimo że w umowie postanowiono o przeniesieniu całości autorskich praw majątkowych. Uregulowanie to wymaga - w celu osiągnięcia możliwości legalnego opracowania utworu - wprowadzenia wyraźnej klauzuli przewidującej taki skutek. Tak więc stosowna klauzula będzie konieczna nawet wtedy, kiedy z umowy wynika, że przy zachowaniu zasad omówionych powyżej umowa w sprawie zamówienia publicznego prowadzi do nabycia całości lub części autorskich praw majątkowych.

Uprawnienia do wykonywania praw zależnych mają istotne praktyczne znaczenie w sytuacji, kiedy zamawiany utwór ma stanowić podstawę do korzystania polegającego na późniejszym jego opracowaniu w rozumieniu art. 2 PrAut, a więc powstania możliwości legalnego stworzenia z wykorzystaniem jego elementów nowego utworu, na przykład w wyniku tłumaczenia, adaptacji lub innej przeróbki (zob. art. 2 ust. 1 PrAut). Brak stosownej klauzuli będzie powodował konieczność uzyskania każdorazowo dodatkowej zgody na zamierzone korzystanie z zastosowaniem wskazanego już powyżej uregulowania art. 67 ust. 1 pkt 1 i 1a PZP.

Ponadto z omawianym tu uregulowaniem PrAut łączy się jeszcze jedna, nie zawsze dostrzegana w praktyce obrotu kwestia - związana $\mathrm{z}$ charakterem prawa do zezwalania na wykonywanie praw zależnych. Aktualnie przyjmuje się, z powołaniem na treść art. 46 PrAut, że jest to prawo majątkowe ${ }^{13}$ i dotyczy jedynie utworów, w odniesieniu do których autorskie prawa majątkowe nie wygasły (zob. art.

${ }^{13}$ Zob. J. Barta, R. Markiewicz, [w:] System prawa prywatnego. Tom 13. Prawo autorskie, red. J. Barta, Warszawa 2003, s. 45-46 i przywołana tam literatura i orzecznictwo. 
2 ust. 2 zd. 1 PrAut). Traktowane jest także jako odrębne pole eksploatacji niewymienione w art. 50 PrAut. ${ }^{14}$ Jego treścią jest udzielanie zgody na rozporządzanie i korzystanie $\mathrm{z}$ opracowania, a więc $\mathrm{z}$ utworu powstałego następczo - na podstawie stanowiącego przedmiot opracowania utworu ,macierzystyego (zob. art. 2 ust. 2 PrAut). Samo stworzenie opracowania (tzw. utworu zależnego) zgody autora utworu macierzystego zasadniczo nie wymaga - wyjątek w tym zakresie dotyczy baz danych spełniających cechy utworu. Jednak legalne korzystanie z takiego opracowania zależy od nabycia stosownych uprawnień w tym zakresie. Przy czym samo nabycie takiego uprawnienia do opracowania utworu pierwotnego nie upoważnia do ingerencji w integralność utworu pierwotnego, chronioną autorskimi prawami osobistymi (zob. art. 16 pkt 3 PrAut). Jedynym wyjątkiem w tym zakresie są programy komputerowe, tylko bowiem w odniesieniu do tej kategorii utworów prawo „tłumaczenia, przystosowywania, zmiany układu lub jakichkolwiek innych zmian w programie komputerowym, z zachowaniem praw osoby, która tych zmian dokonała", stanowi element zbywalnych uprawnień tworzących treść autorskich praw majątkowych (zob. art. 74 ust. 4 pkt 2 PrAut), a autorskie prawa osobiste zostały ograniczone tylko do prawa do autorstwa takiego utworu (zob. art. 77 PrAut). Są to więc uprawnienia zbywalne i możliwe jest ich nabycie.

Kwestia ta w praktyce może okazać się istotna - przepis art. 49 PrAut określa bardzo ogólne zasady wprowadzania zmian do utworów. Wynika z niego, że jeżeli w umowie nie określono sposobu korzystania $\mathrm{z}$ utworu, sposób korzystania (w tym zmian) powinien być zgodny z charakterem i przeznaczeniem utworu oraz przyjętymi zwyczajami, a następca prawny, choćby nabył całość autorskich praw majątkowych, nie może, bez zgody twórcy, czynić zmian w utworze, chyba że są one spowodowane oczywistą koniecznością, a twórca nie miałby słusznej podstawy im się sprzeciwić. Zasada ta odnosi się także do utworów, których czas ochrony autorskich praw majątkowych upłynął. Zwykle przyjmuje się, że dopuszczalne są na tej podstawie bardzo ograniczone zmiany - takie, które nie wpływają na integralność utworu, polegające na przykład na poprawianiu niezamierzonych przez twórcę błędów lub zmian wywołanych zastosowaniem określonej techniki utrwalania lub zwielokrotniania utworu zaakceptowanej uprzednio przez autora jako sposób korzystania z jego dzieła. Podstawa ta może okazać niewystarczająca dla zamierzonej ingerencji w integralność konkretnego utworu, którego dotyczy zamówienie publiczne. Przedstawiany tu problem łatwo zauważyć na tle utworów, które występują w obrocie, w postaci jednostkowych utrwaleń, stanowiących podstawę korzystania z nich - zwłaszcza dotyczy to utrwalonych w postaci obiektu utworów architektonicznych, ale także utworów plastycznych lub fotograficznych. W tego typu sytuacjach skonkretyzowane utrwalenie będące jedynym ucieleśnieniem wkładu in-

${ }^{14}$ Zob. E. Traple, [w:] J. Barta, M. Czajkowska-Dąbrowska, Z. Ćwiąkalski, R. Markiewicz, E. Traple, Prawo autorskie i prawa pokrewne. Komentarz, Kraków 2005, s. 406. 
dywidualnej twórczości nie może być traktowane w obrocie wyłącznie jako rzecz, która stanowi przedmiot dowolnego dysponowania przez właściciela ${ }^{15}$. Wprowadzenie zmian w zakresie treści lub formy będzie bowiem nielegalne i może skutkować odpowiedzialnością za naruszenie autorskich praw osobistych (zob. art. 78 PrAut).

Rozwiązaniem stosowanym w praktyce obrotu przedstawionego tu problemu jest wprowadzenie do treści umowy w sprawie skonkretyzowanego zamówienia publicznego klauzul, które albo legalizują wykonywanie w tym zakresie autorskich praw osobistych, albo przynajmniej upoważniają do określonej ingerencji w elementy treści i formy utworu stanowiącego przedmiot zamówienia publicznego ${ }^{16}$. W świetle wypowiedzi doktryny i orzecznictwa, należy także zastrzec, że klauzule takie, jeśli mają wywierać zamierzony skutek prawny, muszą uwzględniać specyfikę dóbr objętych ochroną autorskimi prawami osobistymi. Zasadniczo wyklucza się skuteczność klauzul prowadzących do nieograniczonej zgody na ingerencję w treść i formę utworu (tzw. klauzule „blankietowe”). Przyjmuje się, że z umowy powinny wynikać co najmniej okoliczności i zakres uzgodnionej ingerencji ${ }^{17}$.

Wiele przepisów PrAut wprowadza dodatkową - w stosunku do zasad ogólnych - i wzmożoną ochronę twórcy utworu w ramach stosunków, na podstawie których następuje nabycie lub korzystanie $\mathrm{z}$ autorskich praw majątkowych. Kwestie szczegółowe z tym związane mogą wymagać doprecyzowania przez odpowiednie klauzule umowne także w umowach dotyczących zamówień publicznych. Dotyczy to możliwości żądania na drodze sądowej wynagrodzenia - na wypadek powstania rażącej dysproporcji między wynagrodzeniem twórcy a korzyściami nabywcy autorskich praw majątkowych lub licencjobiorcy (art. 44 PrAut). Dotyczy to - w dalszej kolejności - uprawnienia do uzyskania informacji oraz wglądu do dokumentacji, mającej istotne znaczenie dla określenia wysokości wynagrodzenia tantiemowego, czyli zależnego od wpływów z korzystania z utworu (art. 47 PrAut). Celowe wydaje się również doprecyzowanie $\mathrm{w}$ umowie dotyczącej zamówienia publicznego zasad, na jakich następować będzie udostępnianie autorowi, zgodnie z art. 52 PrAut, oryginału utworu, jeśli będzie to niezbędne do wykonywania prawa autorskiego oraz określenie formy zabezpieczenia takiego obowiązku oraz wysokości wynagrodzenia (zob. art. 52 ust. 3 PrAut).

Ponadto wskazać należy na dalsze uregulowania PrAut modyfikujące kodeksowe zasady wykonania zobowiązań umownych. Zgodnie z art. 54 PrAut twórca jest obowiązany dostarczyć utwór w terminie określonym w umowie, a jeżeli termin nie został oznaczony - niezwłocznie po ukończeniu utworu. W razie naruszenia tych zasad zamawiający może odstąpić od umowy, ale dopiero po bezskutecznym upływie

${ }^{15}$ Zob. szerzej w odniesieniu do utworów architektonicznych: J. Jezioro, Utwór architektoniczny jako dzieło użytkowe i dobra osobiste jego twórcy, [w:] Dobra osobiste w XXI w. Nowe wartości, zasady technologie, red. J. Balcarczyk, Warszawa 2012, s. 307 i n.

${ }^{16}$ Co do dopuszczalności umownej ingerencji w autorskie prawa osobiste zob. szerzej w: tamże, s. 303 i n.

${ }^{17}$ Zob. szerzej: tamże. 
wyznaczonego odpowiedniego terminu dodatkowego na wykonanie tego obowiązku. Ustawodawca reguluje ogólnie odpowiedzialność za wadliwość utworu - stanowi to modyfikację zasad odpowiedzialności za wady fizyczne i prawne. Odpowiednikiem tych pierwszych są „usterki”, których dotyczy art. 55 ust. 1 PrAut. Zgodnie z tym przepisem, jeżeli zamówiony utwór ma usterki, zamawiający może wyznaczyć twórcy odpowiedni termin do ich usunięcia, a po jego bezskutecznym upływie może od umowy odstąpić lub żądać odpowiedniego obniżenia umówionego wynagrodzenia, chyba że usterki są wynikiem okoliczności, za które twórca nie ponosi odpowiedzialności. Twórca zachowuje w każdym razie prawo do otrzymanej części wynagrodzenia, nie wyższej niż $25 \%$ wynagrodzenia umownego. Roszczenia te wygasają z chwilą przyjęcia utworu. Jeżeli zamawiający w terminie sześciu miesięcy od dostarczenia utworu nie zawiadomi twórcy o jego przyjęciu, nieprzyjęciu lub uzależnieniu przyjęcia od dokonania określonych zmian $\mathrm{w}$ wyznaczonym $\mathrm{w}$ tym celu odpowiednim terminie, uważa się, że utwór został przyjęty bez zastrzeżeń; strony mogą określić inny termin (art. 55 ust. 4). W przypadku wad prawnych zamawiający może od umowy odstąpić i żądać naprawienia poniesionej szkody (art. 55 ust. 2 PrAut).

Specyficznym uprawnieniem twórcy utworu jest prawo odstąpienia od umowy ze względu na istotne interesy twórcze - zgodnie $\mathrm{z}$ art. 56 PrAut twórca może $\mathrm{z}$ tego powodu odstąpić od umowy. Uprawnienie to w sposób istotny osłabia sytuację zamawiającego. Interes tej strony chroni zasada, zgodnie z którą jeżeli w ciągu dwóch lat od tej czynności twórca zamierza przystąpić do korzystania z utworu, ma obowiązek zaoferować to korzystanie nabywcy lub licencjobiorcy, wyznaczając mu w tym celu odpowiedni termin. W przypadku odstąpienia od umowy lub jej wypowiedzenia już po przyjęciu utworu skuteczność tych czynności może być przez drugą stronę umowy uzależniona od zabezpieczenia kosztów poniesionych przez nią w związku z zawartą umową. Przy czym zwrot zwrotu kosztów uzależniony jest tego, czy zaniechanie rozpowszechniania jest następstwem okoliczności, za które twórca ponosi odpowiedzialność. Zasady te zostały wyłączone jedynie w odniesieniu do utworów architektonicznych i architektoniczno-urbanistycznych, audiowizualnych oraz utworów zamówionych w zakresie ich eksploatacji w utworze audiowizualnym.

Elementem omawianych tu umów może być także zobowiązanie nabywcy praw autorskich (odpowiednio licencjobiorcy) do rozpowszechnienia utworu. W takiej sytuacji na podstawie art. 57 PrAut brak przystąpienia do rozpowszechniania utworu w umówionym terminie, a w przypadku braku sprecyzowania terminu - w ciągu dwóch lat od przyjęcia utworu, upoważnia twórcę do odstąpienia od umowy lub jej wypowiedzenia i żądania naprawienia szkody. Przy czym wymaga to bezskutecznego upływu dodatkowego terminu - nie krótszego niż sześć miesięcy. W przypadku zawinionego uchylania się przez nabywcę lub licencjobiorcę od udostępnienia utworu publiczności, stwarza twórcy możliwość domagania się - zamiast naprawienia poniesionej szkody - podwójnego wynagrodzenia w stosunku do tego określonego w umowie o rozpowszechnienie utworu, chyba że licencja jest niewyłączna. Zasady nie znajdują zastosowania do utworów architektonicznych i architektoniczno-urbanistycznych. 
Ogólne skutki odstąpienia od umowy lub jej wypowiedzenia wynikają z art. 59 PrAut. W przypadku braku odmiennych postanowień ustawowych $\mathrm{w}$ takich sytuacjach każda ze stron może żądać od drugiej strony zwrotu wszystkiego, co ta otrzymała z tytułu umowy. Jak się wydaje, także w tym zakresie ustalenie bardziej szczegółowych zasad rozliczeń jest uzasadnione.

Poza przywołanymi juz przepisami art. 49 oraz 52 ust. 3 PrAut, należy też wskazać na dalsze uregulowanie, które wiąże się z korzystaniem z dóbr osobistych twórcy konkretnego utworu. Także w tym zakresie, konstruując stosunek dotyczący realizacji zamówienia publicznego, należy rozważyć zasadność przynajmniej konkretyzacji zasad objętych uregulowaniem PrAut. Według autora dotyczy to zwłaszcza realizacji prawa do nadzoru autorskiego oraz tzw. egzemplarzy autorskich.

Podstawową funkcją nadzoru autorskiego jest zapewnienie autorowi kontroli nad sposobem korzystania z utworu, zwłaszcza z punktu widzenia integralności utworu. Zgodnie $\mathrm{z}$ art. 58 PrAut jeżeli publiczne udostępnienie utworu następuje w nieodpowiedniej formie albo ze zmianami, którym twórca mógłby słusznie się sprzeciwić, może on po bezskutecznym wezwaniu do zaniechania naruszenia odstąpić od umowy lub ją wypowiedzieć. Twórca zachowuje wtedy prawo do wynagrodzenia określonego umową. Stąd też korzystający z utworu ma obowiązek umożliwić twórcy przeprowadzenie takiego nadzoru twórcy jeszcze przed rozpowszechnieniem. Jeżeli wniesione $\mathrm{w}$ związku z nadzorem zmiany w utworze są niezbędne i wynikają z okoliczności od twórcy niezależnych, koszty ich wprowadzenia obciążają nabywcę autorskich praw majątkowych lub licencjobiorcę. W przypadku kiedy twórca nie prowadzi nadzoru autorskiego w odpowiednim terminie, uważa się, że wyraził zgodę na rozpowszechnianie utworu. Zasadniczo za wykonanie nadzoru autorskiego twórcy nie przysługuje wynagrodzenie, ale $z$ art. 60 ust. 4 i 5 PrAut wynikają wyjątki od tej zasady. Wprost w PrAut wynagrodzenie przyznano twórcom utworów plastycznych, a ponadto PrAut w zakresie zasad sprawowania nadzoru autorskiego nad utworami architektonicznymi i architektoniczno-urbanistycznymi odsyła do ustawy z 7 lipca 1994 r. Prawo budowlane ${ }^{18}$.

Szczególne uprawnienia twórców związane z wykonaniem umowy wynikają z postanowień art. 62-63 PrAut. Twórca może w zbiorowej publikacji swych utworów umieścić utwory, o których publikację zawarł odrębną umowę, ale umowa o zbiorowe wydanie utworów nie obejmuje prawa publikacji poszczególnych utworów, chyba że postanowiono w niej inaczej (art. 62 PrAut). Natomiast przepis art. 63 PrAut przyznaje twórcy prawo tzw. egzemplarzy autorskich, jeśli zgodnie z umową egzemplarze utworu mają być przeznaczone do udostępnienia publiczności - ich liczba powinna być określona w umowie, a więc także ten obowiązek wymaga konkretyzacji.

$\mathrm{Na}$ koniec tej części rozważań można też wskazać, że wynagrodzenie autorskie może przybrać postać ryczałtu, ale w praktyce rozpowszechnione jest także uzgadnianie wynagrodzenia stanowiącego pewną część (zwykle określaną procentowo)

\footnotetext{
${ }^{18}$ Tekst jedn.: Dz. U. z 2018 r., poz. 1202 ze zm.
} 
wpływów uzyskiwanych przez nabywcę lub licencjobiorcę potocznie, tzw. wynagrodzenie tantiemowe). Nie ma też przeszkód aby zastosować metodę „mieszaną” - łącząca ryczałt oraz wynagrodzenie tantiemowe. Uzgodnienie wynagrodzenia procentowego powoduje konieczność dookreślenia w treści umowy wielu kwestii związanych z rozliczeniami, stąd metoda ryczałtowa wydaje się znacznie prostsza do zastosowania w praktyce.

\section{Upoważnienie do korzystania z utworów - odrębności umów licencyjnych}

Jak wyjaśniono na wstępie, poza przeniesieniem praw autorskich, możliwe jest także uzyskanie uprawnień do korzystania z utworów na podstawie licencji, czyli upoważnienia do korzystania z utworów. Wydaje się, że w zakresie celów realizowanych $\mathrm{w}$ umowach $\mathrm{w}$ sprawie zamówień publicznych uzyskanie uprawnień licencyjnych będzie bardzo często wystarczające dla realizacji ich celów. W wielu przypadkach w realiach rynkowych będzie to jedyna oferowana możliwość korzystania z utworów - dotyczy to na przykład tzw. użytkowego oprogramowania komputerowego. Ogólnie uzyskanie uprawnień licencyjnych do utworu może mieć też źródło w postanowieniach ustawy (tzw. licencja ustawowa). W pewnym zakresie ustawodawca narzuca też obowiązkowe pośrednictwo w zapłacie za prawo korzystania z określonych utworów organizacjom zbiorowego zarządzania prawami autorskimi lub prawami pokrewnymi, które stosują wzorce umowne w tym zakresie. Te dwie ostatnie sytuacje nie będą omawiane - prezentowane rozważania dotyczą jedynie licencji umownej, a więc sytuacji, kiedy jest ona elementem umowy zawieranej w sprawie zamówienia publicznego.

Umowę licencyjną należy zaliczyć do kategorii umów nazwanych, przy czym na podstawie uregulowania PrAut należy uznać, że jest podstawą do powstania bardzo różniących się w zakresie skutków prawnych, stosunków. Dla przykładu można wskazać, że udzielenie licencji wyłącznej może w bardzo dużym zakresie upodobnić sytuację prawną licencjobiorcy do sytuacji nabywcy praw autorskich. Należy też podkreślić, że ustawodawca wprowadzając w art. 65 PrAut ogólną normę interpretacyjną, z której wynika, że w przypadku braku wyraźnego postanowienia o przeniesieniu prawa uważa się, że twórca udzielił licencji - traktuje ten stosunek jako podstawowy w zakresie uzyskania uprawnień do korzystania z utworów.

Najważniejszą cechą odróżniającą umowy zawierające upoważnienie licencyjne od tych, które przenoszą prawa autorskie (ogół albo na poszczególnych polach eksploatacji), jest jedynie obligacyjny charakter skutku, jaki wywołuje udzielenie licencji. Dla pełności obrazu należy jednak wskazać, że kwestia charakteru prawnego umowy licencyjnej jest sporna $\mathrm{w}$ doktrynie i prezentowana tu ocena ma charakter autorski, ale też zdaje się dominująca w literaturze ${ }^{19}$. Kwestie $\mathrm{z}$ tym związane ze względu na cel i rozmiar tego opracowania nie będą tu omawiane.

${ }^{19}$ Zob. w tej kwestii M. Kępiński, [w:] System prawa prywatnego. Tom 13. Prawo autorskie, red. J. Barta, Warszawa 2003, s. 472 i n. i przywołana tam literatura i orzecznictwo. 
Na podstawie PrAut, umowa licencyjna jest umową, która zawiera upoważnienie do terminowego - lub bez oznaczenia terminu - korzystania, w oznaczonym zakresie, z określonego dobra niematerialnego (np. z utworu lub przedmiotów praw pokrewnych), na określonych polach eksploatacji. Może to być umowa odpłatna lub nieodpłatna. W przypadku udzielenia licencji wyłącznej, jak już wskazano, wymagane jest dochowanie formy pisemnej pod rygorem nieważności (art. 67 ust. 5 PrAut). Ze względu na swoistą ,elastyczność” uregulowania PrAut dotyczącego licencji skonstruowanie konkretnego stosunku z umową licencyjnej wymaga dokonania wielu istotnych dookreśleń dotyczących jej rodzaju i zakresu. Ogólnie brak sprecyzowania tych kwestii powoduje, że zastosowanie znajdą zasady ustawowe, co niejednokrotnie może być źródłem zbędnych sporów.

I tak brak określenia terminu korzystania powoduje, że licencja uprawnia do korzystania z utworu w okresie pięciu lat, a brak określenia zakresu terytorialnego powoduje zawężenie go do terytorium państwa, w którym licencjobiorca ma swoją siedzibę (art. 66 zd.1 PrAut). W sytuacji takiej licencjobiorca nie może upoważnić innej osoby do korzystania z utworu w zakresie uzyskanej licencji (art. 67 ust. 3 PrAut). Zatem skonkretyzowana licencja powinna-zgodnie z art. 67 ust. 1 PrAut-zawierać umowne wskazanie pól eksploatacji z określeniem zakresu, miejsca i czasu korzystania z utworu, na który została udzielona. Udzielenie licencji wyłącznej prowadzi do istotnego wzmocnienia sytuacji prawnej licencjobiorcy - powstaje wyłączność korzystania z utworu w określony sposób na rzecz licencjobiorcy, a dodatkowo, jeśli umowa nie stanowi inaczej, uprawniony z licencji wyłącznej może dochodzić roszczeń z tytułu naruszenia autorskich praw majątkowych, w zakresie objętym umową licencyjną (art. 67 ust. 4 PrAut). Jak wskazano powyżej, sytuacja takiego licencjobiorcy istotnie zbliża się do sytuacji nabywcy praw autorskich, co oznacza, iż w wielu przypadkach udzielenie licencji wyłącznej może być swoistym ,ekwiwalentem" nabycia praw autorskich. Jedyną istotną różnicą w takiej sytuacji jest trwałość stosunku powołanego przez umowę licencji wyłącznej. Wynika to z art. 68 PrAut, który stanowi, że jeżeli umowa nie stanowi inaczej, a licencji udzielono na czas nieoznaczony, twórca może ją wypowiedzieć z zachowaniem terminów umownych, a w razie ich braku - na rok naprzód, na koniec roku kalendarzowego, a jednocześnie licencję udzieloną na okres dłuższy niż pięć lat, po upływie tego terminu, uważa się za udzieloną na czas nieoznaczony. Przywołane tu uregulowanie ma w zasadniczym zakresie charakter bezwzględnie wiążący i prowadzi do sytuacji, w której nie ma możliwości definitywnego nabycia uprawnień licencyjnych. Po upływie pięciu lat każda umowa licencyjna może być wypowiedziana przez strony. Jest to podstawowy skutek zawarcia takiej umowy, który należy odnieść do skonkretyzowanego celu zamówienia publicznego. 


\section{Ogólne podsumowanie}

Przechodząc do ogólnego podsumowania prowadzonych w artykule rozważań, należy wskazać przede wszystkim na następujące kwestie praktyczne związane z omówionymi powyżej bardziej szczegółowo odmiennościami uregulowania PrAut.

W pierwszym rzędzie w praktyce udzielania zamówień publicznych istotne jest dobranie odpowiedniego do skonkretyzowanego celu zamówienia publicznego zakresu nabywanych uprawnień do przedmiotów prawa autorskiego, które mają powstać w wyniku jego realizacji. Możliwy wybór oznacza zwłaszcza wybór pomiędzy umowami przenoszącymi prawa autorskie (prawa pokrewne lub prawa do baz danych sui generis) a umowami zawierającymi upoważnienie do korzystania $\mathrm{z}$ dóbr prawa autorskiego (umowami licencyjnymi), a także wybór odpowiedniego zakresu pól eksploatacji, które powinny być „odbiciem” zamierzonego sposobu korzystania $\mathrm{z}$ tych dóbr.

W drugiej kolejności w odniesieniu do zamówienia, którego skonkretyzowanym celem jest uzyskanie uprawnień do utworów oraz artystycznych wykonań istotne jest zapewnienie możliwości wykonywania lub korzystania z niezbywalnych uprawnień chroniących autorskie prawa osobiste. Jak bardziej szczegółowo wykazano to w treści tej pracy - zwłaszcza dotyczy to prawa do integralności, a więc możliwości legalnego wprowadzania zmian do przedmiotu zamówienia publicznego, który jest utworem lub artystycznym wykonaniem.

Na sam koniec należy podkreślić, że zakres omówionych w opracowaniu uregulowań może w praktyce mieć duże znaczenie dla praktyki zamówień publicznych. Poza już przywołanymi przykładami wskazać należy zwłaszcza na umowy zawieranych $w$ ramach uregulowania dotyczącego partnerstwa innowacyjnego (art. 73h PZP) oraz konkursów, w przypadku których podstawowym celem udzielenia zamówienia publicznego jest uzyskanie praw do przedmiotów prawa autorskiego czy szerzej własności intelektualnej - a więc także przedmiotów własności przemysłowej, czym tutaj autor się nie zajmował, ograniczając rozważania do prawa autorskiego (art. 110 PZP). Oba te przykłady bodaj najlepiej ilustrują przedstawione w opracowaniu problemy wynikające z odmienności uregulowania PrAut, a zwłaszcza te wynikające $\mathrm{z}$ uregulowania chroniącego autorskie prawa osobiste. W obu tych przypadkach celem zamówienia publicznego jest uzyskanie praw do przedmiotów własności intelektualnej - w przypadku konkursu jest to praca „, z zakresu planowania przestrzennego, projektowania urbanistycznego, architektoniczno-budowlanego oraz przetwarzania danych". Natomiast w przypadku partnerstwa innowacyjnego wiąże się to dodatkowo z „etapowością” realizacji zamówienia dotyczącego procesu badawczo-rozwojowego oraz możliwością zmniejszenia liczby partnerów. Na każdym $\mathrm{z}$ etapów mogą bowiem pojawić się objęte ochroną prawa autorskiego wyniki stanowiące cele pośrednie, do których w zakresie dóbr prawa autorskiego zasadniczo pierwotnie uprawnieni będą ich autorzy. A przy tym dalsze ich legalne wykorzystanie wymaga istnienia umownej podstawy do zapewnienia finalnego korzystania 
z nich zgodnie z celem skonkretyzowanego zamówienia publicznego - a więc dookreślenia zakresu i nabywanych uprawnień majątkowych, jak również zapewnienia możliwości zmian i opracowań ingerujących w integralność takich efektów.

\section{Literatura}

Barta J., Markiewicz R., [w:] Prawo autorskie i prawa pokrewne. Komentarz, Kraków 2005.

Barta J., Markiewicz R., [w:] System prawa prywatnego. Tom 13. Prawo autorskie, red. J. Barta, Warszawa 2003.

Jezioro J., Utwór architektoniczny jako dzieło użytkowe i dobra osobiste jego twórcy, [w:] Dobra osobiste w XXI w. Nowe wartości, zasady technologie, red. J. Balcarczyk, Warszawa 2012.

Kępiński M., [w:] System prawa prywatnego. Tom 13. Prawo autorskie, red. J. Barta, Warszawa 2003.

Szczotka J., Naruszenie wymogu specyfikacji pól eksploatacji utworu, [w:] Wspótczesne problemy prawa handlowego. Ksiegga jubileuszowa dedykowana prof. dr hab. Marii Poźniak-Niedzielskiej, red.

A. Kidyba, R. Skubisz, Kraków 2007.

Targosz T., [w:] T. Targosz, K. Włodarska, Umowy przenoszace autorskie prawa majątkowe, Warszawa 2010.

Traple E., [w:] J. Barta, M. Czajkowska-Dąbrowska, Z. Ćwiąkalski, R. Markiewicz, E. Traple, Prawo autorskie i prawa pokrewne. Komentarz, Kraków 2005,

Żerański P., Formy umów autorskich na tle zasady specyfikacji, Glosa, 2007, nr 3. 